\title{
Seasonal Partitioning of Leaf and Fruit Potassium and Fruit Dry Matter in French Prune Trees at Various Potassium Levels
}

\author{
F.J.A. Niederholzer', R.M. Carlson, K. Uriu, N.H. Willits' ${ }^{2}$ and J.P. Pearson \\ Department of Pomology, University of California, Davis, CA 95616
}

Additional index words. Prunus domestics, fruit crops, plant nutrition

\begin{abstract}
A study was undertaken to determine the seasonal dynamics of leaf and fruit $\mathrm{K}$ content and the influence of tree $\mathrm{K}$ status and fruit growth on leaf and fruit $\mathrm{K}$ accumulation rates in French prune (Prunus domestics $\mathbf{L}$. CV. d'Agen). Mature trees in a commercial orchard were treated with various rates of $\mathrm{K}^{2} \mathrm{SO}_{4}$. $(\mathrm{O}$ to $\approx 20 \mathrm{~kg} / \mathrm{tree})$ in the fall. Fruit dry weight yield per tree at harvest and fruit $K$ content were higher for high-K trees, but fruit percent $K$ (by dry weight) was $\approx 1.0 \%$ for all trees. Leaf scorch and subsequent abscission severely reduced the canopy of $K$ deficient trees. Significant positive linear relationships between leaf and fruit $K$ accumulation rates existed for the periods of 28 Apr.-28 May (May) and 28 May-7 July (June). A significant negative linear relationship existed between these two criteria from 7 July-3 Aug. (July). May $(0.237 \mathrm{mg} \mathrm{K}$ per fruit-day) and July (0.267 mg K per fruit-day) mean fruit $\mathrm{K}$ accumulation rates were similar, but both were significantly higher $(P=0.001)$ than those for June $(0.140 \mathrm{mg} K$ per fruit-day). Mean leaf $\mathrm{K}$ accumulation rates for May (- $0.007 \mathrm{mg} \mathrm{K}$ per leaf-day) and July (-0.010 mg K per leaf-day) were similar, but both were significantly $(P=0.001)$ less than for June $(0.005 \mathrm{mg} \mathrm{K}$ per leafday). Potassium per fruit accumulation was highest in trees with highest $K$ status. Periods of net leaf $K$ efflux and influx did not precisely correlate with fruit growth stages measured by fruit dry weight. The period of lowest fruit $\mathrm{K}$ accumulation ( 28 May-7 July) coincided with the period of maximum dry matter accumulation by the kernel. After 7 July, all increases in fruit dry weight and $\mathrm{K}$ content were due to mesocarp growth.
\end{abstract}

Potassium is a phloem-mobile macronutrient and consequently available for translocation from mature leaves to developing tissues (Greenway and Pitman, 1965). Leaves and, to a lesser degree, shoots (Conradie, 1981; Widders and Lorenz, 1982) represent a labile pool of $\mathrm{K}$ within plants. Late-season loss of leaf $\mathrm{K}$ concurrent with fruit $\mathrm{K}$ accumulation have been reported for peach [Prunus persica (L.) Batsch.] (Batjer and Westwood, 1958), kiwifruit [Actinidia deliciosa (A. Chev.) C.F. Liang et. R. Ferguson] (Smith et al., 1987), mandarins (Citrus reticulata Blanco) (Golomb and Goldschmidt, 1987), and pecans [Carya illinoensis (Wangenh.) K. Koch] (Sparks, 1977). Leaf $\mathrm{K}$ content and concentration of de fruited pecan trees do not decrease before leaf abscission (Sparks, 1977).

Fruit $\mathrm{K}$ and dry matter accumulation are linearly correlated (Hansen, 1980; Rogers and Batjer, 1953), although the physiological mechanism of the relationship is not understood. Potassium enhances phloem transport (Mengel, 1985). Pecan leaf K-deficiency symptoms first develop close to fruit, a pattern similar to carbon translocation from leaves to fruit (Sparks, 1977). A similar spatial relationship between leaves of decreasing $\mathrm{K}$ content and developing fruit is reported for kiwifruit (Smith et al., 1987).

In French prune orchards of Northern California, moderate to heavy crop loads have been correlated with leaf K-deficiency symptoms (Lilleland, 1932) resulting in reductions of crop yield, fruit quality, and income per unit area (Olson et al., 1987). In extreme cases, K-deficiency symptoms include shoot and limb die-back, and, occasionally, tree death (Lilleland, 1932). The relationship between fruiting and leaf $\mathrm{K}$ deficiency symptoms

Received for publication 15 Oct. 1990. We thank Richard McGowan of McGowan Orchards, Chico, Calif., for permission to carrv out this studv in his orchard. and S.A. Weinbaum and T.M DeJong for their ;eviews of this-manuscript. The cost of publishing this paper was defrayed in part by the payment of page charges. Under postal regulations, this paper therefore must be hereby marked advertisement solely to indicate this fact.

'To whom reprint requests should be addressed.

'Senior Statistician, Division of Statistics. of French prune has primarily been studied through fruit thinning or complete crop removal followed by leaf and stem $\mathrm{K}$ and carbohydrate analysis (Hansen et al., 1982; Lilleland, 1932; Lilleland and Brown, 1938; Ryugo et al., 1977). We found no reports comparing rates of leaf and fruit $\mathrm{K}$ and dry weight accumulation. Nor did we find any reports examining the possible influence of the development of the several fruit components (mesocarp, endocarp, and seed) on leaf $\mathrm{K}$ levels.

The objective of this study was to investigate the seasonal relationship of leaf and fruit $\mathrm{K}$ accumulation rates among French prune trees of varying $\mathrm{K}$ status that did not undergo fruit thinning.

\section{Materials and Methods}

The experiment was conducted in a commercial planting of 13-year-old French prune trees on Marianna 2624 (Prunus cerasifera $\times P$. munsoniana?) rootstock west of Chico, Calif. The soil, a Farwell adobe clay (Watson et al., 1929), is weakly developed with a clay loam (27\% to $40 \%$ clay) surface texture grading to loam ( $8 \%$ to $27 \%$ clay) deeper in the profile. Ammonium acetate extractable $\mathrm{K}$ ranges from 100 to $200 \mathrm{ppm}$. Extractable $\mathrm{K}$ by boiling $\mathrm{HNO}_{3}$ is 170 to $300 \mathrm{ppm}$. These values fall in the lower range of 96 California soils examined for plant K availability (Brown et al., 1973).

Leaf analysis was conducted in Fall 1986 to determine the K status of potential study trees. Ten control trees were selected with low to adequate $\mathrm{K}$ ( 1.090 to $1.3 \% \mathrm{~K}$ by dry weight) and received no additional $\mathrm{K}$. Eight treatment trees were chosen with higher $\mathrm{K}(1.3 \%$ to $2.2 \% \mathrm{~K}$ by dry weight), and each received a different amount of $\mathrm{K}_{2} \mathrm{~S} \mathrm{O}_{4}(19.8,17.8,15.8,13.3,10.9,8.9$, 6.9 , or $4.9 \mathrm{~kg}$ ) in one application. The $\mathrm{K}_{2} \mathrm{~S} \mathrm{O}_{4}$ was trenched to a depth of $15 \mathrm{~cm}$ at the drip line in Fall 1986. Guard trees buffered the study plot from foliar and soil $\mathrm{K}$ applications in the commercial orchard.

Leaf and fruit sampling began on 14 Apr. 1987, 17 days after full bloom, and continued until 17 Aug., 1 week before harvest. Fully expanded spur leaves and fruit were sampled simulta- 
neously throughout the season and washed. Subsequent to 14 May, each fruit was divided into mesocarp and exocarp(mesocarp), endocarp, and kernel.

In May, when K-deficiency symptoms first appeared, the study trees were rated for intensity of K-deficiency symptoms. Scores ranged from 1 (no deficiency symptoms) to 9(slight to moderate deficiency symptoms).

The three stages of fruit growth (Connors, 1919) were determined by plotting mean rate of change of fruit dry weight and noting the inflection points. At harvest, fruit dry weight per tree was estimated by determining fresh fruit volume per tree in the field and subsequent determination of the dry weight of a freshfruit subsample of known volume.

All tissues were dried in a forced-air oven at $60 \mathrm{C}$ and weighed. Leaf tissue was ground in a Wiley mill to pass a 20-mesh screen. Mesocarp samples were pulverized in a Waring electric coffee grinder. Endocarp samples were broken up in the coffee grinder and then ground to pass a 20-mesh screen. Kernels were ground in a mortar and pestle. Whole-fruit data were obtained by summing the partitioned fruit data. Potassium determination was by flame photometry following extraction with $2 \%$ acetic acid.

Analysis of covariance with repeated measures (BMDP2V: Dixon, 1985) was used to determine the statistically significant relationships within the data. The tree was treated as the experimental unit, with the sampling date as the within-factor, and leaf $\mathrm{K}$ was treated as a time-varying covariate. There were no grouping factors in this model, since the treatment was applied to induce differences in available $\mathrm{K}$. Orthogonal decomposition was included in the analysis. Data from 28 Apr.-28 May (May), 28 May-7 July (June), and 7 July-3 Aug. (July) were analyzed in this manner. These intervals were chosen after examination of the trends in leaf and fruit $\mathrm{K}$ content. Nonsignificant portions of the original tables are not presented. Significant linear relationships (Table 2 A-C) are presented graphically (Figs. 3-5). Significant differences in estimated fruit and leaf $\mathrm{K}$ accumulation rates between May, June, and July were determined by paired $t$ tests. No multiple comparisons adjustment was made for these three pair-wise comparisons. The individual data points that appear in Figs. 2-4, which were used to calculate the data in Table 3, are estimates of the rate of fruit or leaf accumulation obtained from the slope of the regression line through the data points for that particular time interval. These estimated rates will be referred to as rates.

Levels of $\mathrm{N}, \mathrm{P}, \mathrm{Ca}, \mathrm{Mg}, \mathrm{Zn}, \mathrm{Mn}, \mathrm{Na}, \mathrm{Cl}$, and $\mathrm{B}$ were determined in all leaf, mesocarp, and endocarp samples for all sampling dates. For these nine nutrients, no deficiency symptoms were observed in the field nor were deficient levels determined through leaf analysis (Niederholzer, 1990).

\section{Results}

Only two trees (1 and 2) contained midseason leaf percent $\mathrm{K}$ considered adequate by Cooperative Extension of Univ. of California (Uriu, 1982) (Table 1). All the trees considered deficient by midsummer leaf $\mathrm{K}$ levels showed some $\mathrm{K}$ deficiency symptoms in late May (Table 1). Fruit dry weight at harvest was higher for high-K than for low- $\mathrm{K}$ trees. However, fruit $\mathrm{K}$ concentration was similar for all trees by early July (Table 1). All control trees suffered at least 50\% defoliation through leaf scorch and abscission by harvest, while treated trees that were deficient in $\mathrm{K}$ suffered some defoliation. By observation, the degree of defoliation appeared related to tree $\mathrm{K}$ status.

Fruit accumulated $\mathrm{K}$ throughout the season (Fig. 1). Trees with high $\mathrm{K}$ (Table 1) accumulated fruit $\mathrm{K}$ at higher rates than trees with low $\mathrm{K}$ during May, June, and July (Figs. 3-5).

In contrast to the season-long accumulation of fruit $\mathrm{K}$, rates and directions of leaf $\mathrm{K}$ net flux, and consequently leaf $\mathrm{K}$ content, varied with time (Figs. 1, 3, 4, and 5). During May, June, and July, significant linear relationships were determined between rates of leaf and fruit $\mathrm{K}$ flux (Table 2 A-C; Figs. 3-5). These relationships were positive in May and June (Table 2 A, B; Figs. 3 and 4) with regression coefficients of $7.46 \Delta$ fruit $\mathrm{mg} \mathrm{K} / \Delta$ leaf $\mathrm{K}$ (May) and $5.92 \Delta$ fruit $\mathrm{mg} \mathrm{K} / \Delta$ leaf $\mathrm{K}$ (June). Despite the similar magnitude and positive sign of the relationship between leaf and fruit accumulation rates during May and June, 16 of 18 study trees lost leaf K during May (Fig. 3) while leaves of only three trees lost $\mathrm{K}$ during June. From June to July, the sign of the linear relationship between rate of leaf and fruit $\mathrm{K}$ changed and the magnitude of the regression coefficient doubled (Table 2A, B).

Mean fruit accumulation rates for May and July were similar (Table 3), but both were significantly higher than June. The mean June leaf $\mathrm{K}$ accumulation rate was significantly higher than in July or May, both of which were negative (Table 3).

Fruit growth measured by dry weight accumulation followed a double sigmoid curve (Fig. 6). Trends in leaf $\mathrm{K}$ net fluxes did not coincide precisely with the fruit growth stages (Fig. 1).

No $\mathrm{K}$ accumulated in the endocarp or kernel during stage 3 (Fig. 2). Therefore, the high rates of fruit $\mathrm{K}$ accumulation during July are actually mesocarp $\mathrm{K}$ accumulations. No endocarp dry matter accumulation occurred during stage 3. Kernel dry weight accumulation ceased after 7 July (Fig. 6).

\section{Discussion}

French prune midsummer leaf $\mathrm{K}$ of $>1.3 \%$ and $<1.0 \%$ by dry weight is considered adequate and deficient, respectively. Leaf $\mathrm{K}$ concentrations of $2.0 \%$ to $3.0 \%$ (by dry weight) are not uncommon for Sacramento Valley orchards (R. M. C., unpublished). Despite $\mathrm{K}$ fertilizer application rates ranging from very high (19.8 $\mathrm{kg} \mathrm{K}_{2} \mathrm{~S}_{4}$ per tree) to low (4.8 $\mathrm{kg} \mathrm{K} \mathrm{K}_{2} 0_{4}$ per tree) (K.U., personal communication), midsummer tree $\mathrm{K}$ levels ranged from adequate to very deficient (Table 1).

The high K demand of the large 1987 crop and the fine texture and low $\mathrm{K}$ content of the soil may have contributed to the low range of midsummer leaf $\mathrm{K}$ levels obtained in this study. Reduced response to $\mathrm{K}$ fertilization in the year following application has been reported in fine-textured soils (Uriu et al., 1980). Potassium is diffusion-limited in most agricultural soils (Barber, 1985). Diffusion is negatively correlated with clay content and soil moisture (Barber, 1985). As nutrient depletion zones around roots can develop rapidly, new root growth must occur if adequate uptake is to continue. The fine soil texture and temporal range of soil moisture content undoubtedly produced by the irrigation method (gated pipe) may have reduced soil $\mathrm{K}$ diffusion rates in the study orchard relative to a coarser-textured soil. If soil $\mathrm{K}$ levels are low and fertilizer is applied to a small soil volume, the importance of new root growth for adequate $\mathrm{K}$ nutrition is increased. Cropping has been demonstrated to reduce root growth in horticultural crops (Hansen, 1980; Williamson and Coston, 1989).

Reduced yield per tree in K-deficient French prune (Table 1) has been reported (Olson et al., 1987). Since the fruit K concentrations were not affected by tree $\mathrm{K}$ (Table 1), the greatest effect of $\mathrm{K}$ deficiency upon fruit yield may have been through defoliation and resulting loss of tree photosynthetic capacity.

Because only leaf and fruit $\mathrm{K}$ contents were measured during 
Table 1. Potassium concentrations in fully expanded spur leaves (by percent dry weight) of all study trees in Fall 1986 and on 7 July 1987, quantity of Fall 1986-applied $\mathrm{K}_{2} \mathrm{SO}_{4}$, visual K deficiency symptoms 22 May 1987, mean fruit K concentrations ( \pm SD) for 7 July-17 Aug. 1987, and fruit dry weight at harvest.

\begin{tabular}{|c|c|c|c|c|c|c|}
\hline Tree & $\begin{array}{c}\text { Leaf K } \\
30 \text { Sept. } 1986 \\
(\%) \\
\end{array}$ & $\begin{array}{c}\mathrm{K}_{2} \mathrm{SO}_{4} \\
\text { applied Oct. } \\
1986 \\
(\mathrm{~kg}) \\
\end{array}$ & $\begin{array}{c}\text { Tree K } \\
\text { deficiency ratingz } \\
\text { 22. May } 1987\end{array}$ & $\begin{array}{c}\text { Leaf K } \\
\begin{array}{c}7 \text { July } 1987 \\
(\%)\end{array} \\
\end{array}$ & $\begin{array}{c}\text { Mean fruit K } \\
7 \text { July-17 Aug. } \\
1987 \\
(\%) \\
\end{array}$ & $\begin{array}{c}\text { Fruit dry wt, } \\
1987 \\
(\mathrm{~kg} / \text { tree }) \\
\end{array}$ \\
\hline 1 & 2.06 & 19.8 & 1 & $1.67^{y}$ & $1.16( \pm 0.10)$ & 54 \\
\hline 2 & 1.67 & 4.9 & 1 & $1.33^{y}$ & $1.10( \pm 0.09)$ & 55 \\
\hline 3 & 2.01 & 15.8 & 1 & $1.20^{x}$ & $1.04( \pm 0.08)$ & 43 \\
\hline 4 & 1.01 & 13.3 & 1 & $1.01^{x}$ & $1.08( \pm 0.07)$ & 35 \\
\hline 5 & 2.16 & 17.8 & 2 & $0.93^{w}$ & $1.22( \pm 0.07)$ & 25 \\
\hline 6 & $1.32 \div$ & 6.9 & 2 & $0.89^{w}$ & $1.13( \pm 0.14)$ & 31 \\
\hline 7 & 1.74 & 10.9 & 3 & $0.71^{w}$ & $1.08( \pm 0.13)$ & 32 \\
\hline 8 & 1.91 & 8.9 & 2 & $0.67^{w}$ & $1.06( \pm 0.14)$ & 26 \\
\hline 9 & 1.08 & 0 & 4 & $0.56^{\mathrm{w}}$ & $1.01( \pm 0.12)$ & ND \\
\hline 10 & 1.30 & 0 & 8 & $0.42^{w}$ & $1.00( \pm 0.09)$ & 23 \\
\hline 11 & 1.06 & 0 & 9 & $0.41^{\mathrm{w}}$ & $1.01( \pm 0.08)$ & ND \\
\hline 12 & 1.46 & 0 & 6 & $0.41^{w}$ & $1.04( \pm 0.13)$ & 26 \\
\hline 13 & 1.54 & 0 & 8 & $0.41^{w}$ & $1.21( \pm 0.26)$ & 16 \\
\hline 14 & 1.33 & 0 & 8 & $0.39^{w}$ & $0.97( \pm 0.07)$ & ND \\
\hline 15 & 1.30 & 0 & 5 & $0.39^{w}$ & $1.16( \pm 0.07)$ & 32 \\
\hline 16 & 1.29 & 0 & 5 & $0.39^{w}$ & $1.17( \pm 0.09)$ & 17 \\
\hline 17 & 1.16 & 0 & 8 & $0.38^{w}$ & $0.94( \pm 0.08)$ & ND \\
\hline 18 & 1.08 & 0 & 9 & $0.37^{w}$ & $1.04( \pm 0.13)$ & ND \\
\hline
\end{tabular}

${ }^{2}$ Rating scale, $1=$ no deficiency symptoms, $9=$ slight/moderate deficiency symptoms.

$\mathbf{y , x , w}$ Indicates adequate, marginal, and deficient tree $\mathbf{K}$ status, respectively, as set by Univ. of California Cooperative Extension (Uriu, 1982).

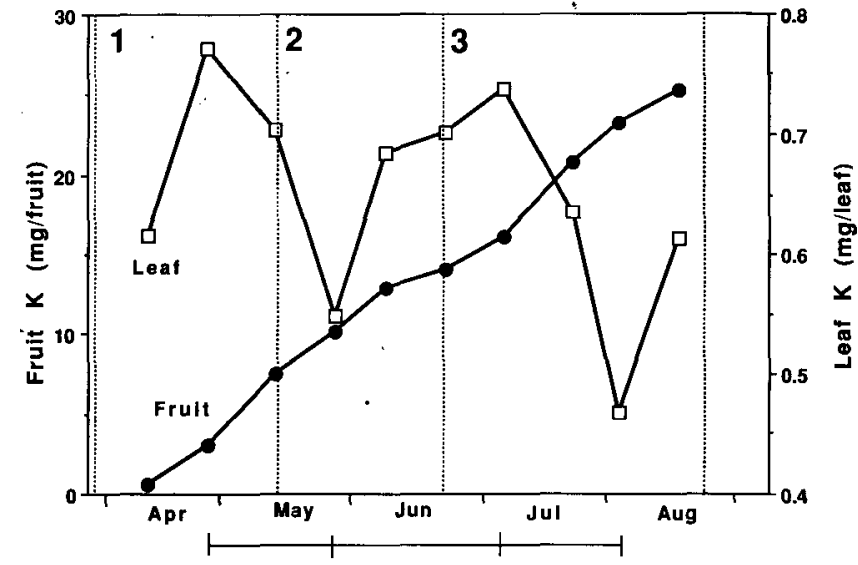

Fig. 1. Mean $(\mathrm{n}=18)$ of leaf $(\mathrm{mg} / \mathrm{leaf})$ and whole-fruit $(\mathrm{mg} / \mathrm{fruit})$ ' $\mathrm{K}$ contents with time. The vertical dotted lines indicate the three stages of prune fruit growth. The bars below the $\mathrm{X}$-axis indicate the sampling dates represented in Figs. 3-5.

this experiment, it is impossible to quantify whole-plant $\mathrm{K}$ movement with time. However, leaf, shoot, and fruit are the only tissues that demonstrate net $\mathrm{K}$ fluxes through the growing season for young, bearing peach (Stassen and Stadler, 1988) and grape (Conradie, 1981). In mature prune trees, cropping decreases $\mathrm{K}$ concentration in the leaves, current growth, 1-yearold shoots, and limb bark (Hansen et al., 1982). We therefore assume that the majority of leaf $\mathrm{K}$ translocated from leaves after cessation of shoot growth accumulated in the fruit, not other portions of the tree.

Interpretation of the data for May is difficult because shoot growth was not measured. Shoot growth is a carbon and mineral nutrient sink (Stassen and Stadler, 1988) and has been shown to reduce root growth (Head, 1967). The spring $\mathrm{K}$ stress and consequent leaf $\mathrm{K}$ efflux observed in 16 of 18 study trees may

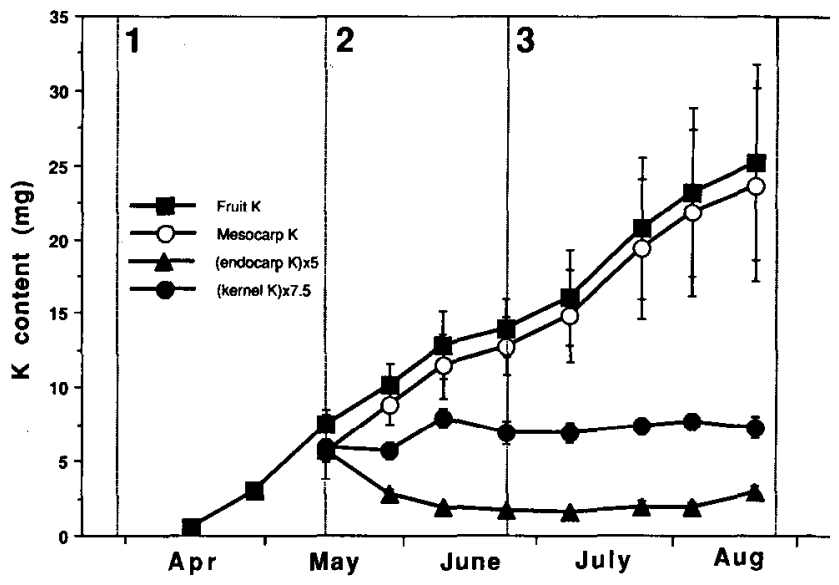

Fig. 2. Whole fruit, mesocarp, (endocarp) x 5, and (kernel) $x 7.5$ $\mathrm{K}$ content (mg/fruit) with time. Bars represent SD. Vertical dotted lines indicate the three stages of prune fruit growth.

have been caused by the combination of several factors: strong $\mathrm{K}$ sink strengths of shoot and fruit, insufficient root growth/ activity to exploit soil $\mathrm{K}$ resources, and the exhaustion of tree $\mathrm{K}$ reserves.

Previous studies of French prune $\mathrm{K}$ nutrition have focused on mid- to late summer when leaf $\mathrm{K}$ deficiency symptoms are most severe. However, several of these researchers reported reduced leaf $\mathrm{K}$ concentration (Uriu et al., 1980), milligrams of $\mathrm{K}$ per square millimeter of leaf area (Hansen et al., 1982), and leaf $K$ content (Lilleland, 1932) in May and early June followed by mid-June recovery. These are data similar to those presented by us.

Exhaustion of $\mathrm{K}$ reserves and high spring $\mathrm{K}$ demand by shoots and fruit may result in a transient $\mathrm{K}$ deficiency in late spring. Such a deficiency could be of particular concern in i) orchards of low to marginal soil $\mathrm{K}$, ii) trees of low $\mathrm{K}$ reserves the year 


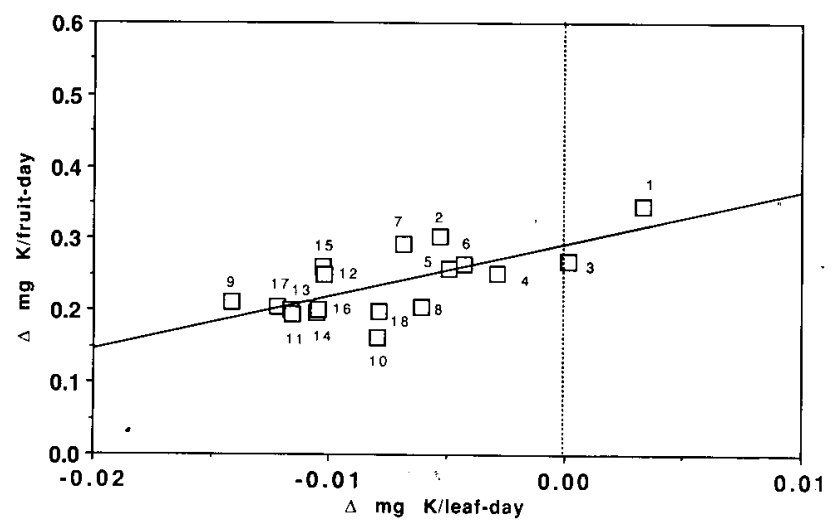

Fig.3. Changes in leaf ( $\Delta \mathrm{mg} \mathrm{K} /$ leaf-day) and whole-fruit $\mathrm{K}$ content ( $\Delta \mathrm{mg}$ K/fruit-day) for 18 trees from 28 Apr.-28 May 1987. The numbers beside each data point indicate the $\mathrm{K}$ status ranking of the tree (Table 1) represented by that point.

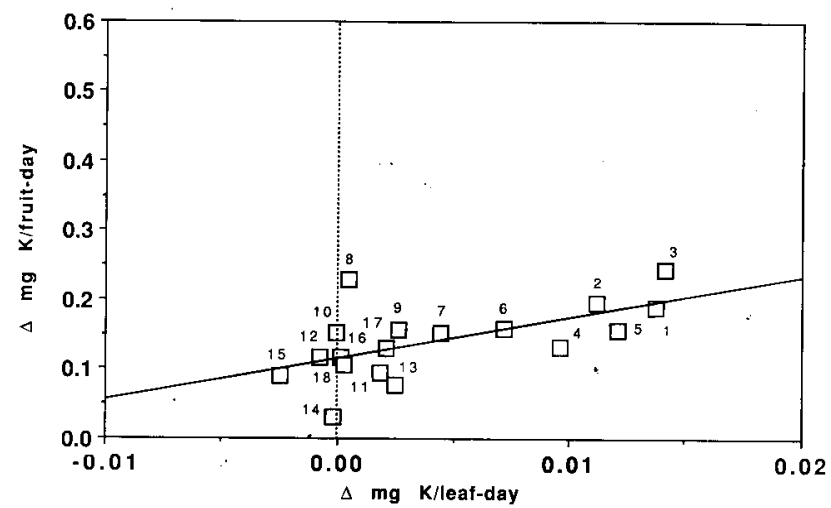

Fig.4. Changes in leaf ( $\Delta \mathrm{mg} \mathrm{K} /$ leaf-day) and whole-fruit Kcontent ( $\Delta \mathrm{mg} \mathrm{K}$ /fruit-day) for 18 trees from 28 May-7 July, 1987. The numbers beside each data point indicate the $\mathrm{K}$ status ranking of the tree (Table 1) represented by that point.

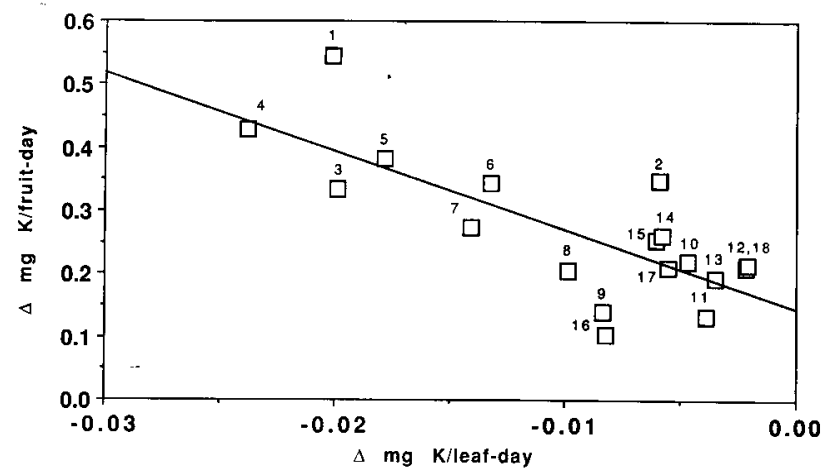

Fig. 5. Changes in leaf ( $\Delta \mathrm{mg} \mathrm{K} /$ leaf-day) and whole fruit $\mathrm{K}$ content ( $\Delta \mathrm{mg} \mathrm{K/fruit-day)} \mathrm{for} 18$ trees from 7 July-3 Aug. 1987. The numbers beside each data point indicate the potassium status ranking of the tree (Table 1) represented by that point.

following a heavy crop, and/or iii) a heavy crop year with attendant high fruit $\mathrm{K}$ demand. Leaf damage from spring $\mathrm{K}$-deficiency symptoms might damage the photosynthetic capacity of low-K trees at a time when carbon demand is presumed to be high. Further research on spring $\mathrm{K}$ accumulation in leaves, fruit, and shoots may reveal economic advantages to management practices that maintain adequate early season leaf $\mathrm{K}$.

Mature leaves are a labile pool from which $\mathrm{K}$ can be translocated when plant $\mathrm{K}$ demand is not met by soil $\mathrm{K}$ uptake (Con-
Table 2. Analysis of covariance for the effect of leaf $\mathrm{K}$ content on fruit $\mathrm{K}$ content of French prune trees.

\begin{tabular}{|c|c|c|c|c|c|}
\hline Source & $\begin{array}{l}\begin{array}{l}\text { Sum of } \\
\text { squares }\end{array} \\
\end{array}$ & $\mathrm{df}$ & Mean square & $\mathrm{F}$ values & $\begin{array}{l}\text { Regression } \\
\text { coefficients }\end{array}$ \\
\hline \multicolumn{6}{|c|}{ A. 28 Apr. -28 May } \\
\hline Leaf $\mathrm{K}$ & 18.303 & 1 & 18.303 & $18.88 * * *$ & 3.532 \\
\hline Error & 15.513 & 16 & 0.969 & & \\
\hline Linear & 180.357 & 1 & 180.357 & $330.63 * * *$ & \\
\hline Leaf $\mathrm{K}$ & 8.686 & 1 & 8.686 & $15.92 * *$ & 7.457 \\
\hline Error & 8.727 & 16 & 0.545 & & \\
\hline Total & 229.916 & 2 & 114.958 & $285.61 * * *$ & \\
\hline Leaf $\mathrm{K}$ & 7.591 & 1 & 7.591 & $18.86 * * *$ & 6.316 \\
\hline Error & 13.282 & 33 & 0.402 & & \\
\hline \multicolumn{6}{|c|}{ B. 28 May-7July } \\
\hline Leaf $\mathrm{K}$ & 231.927 & 1 & 231.927 & $63.277^{*} "$ & 5.901 \\
\hline Error & 58.653 & 16 & 3.666 & & \\
\hline Linear & 128.305 & 1 & 128,305 & $74.83 * * *$ & \\
\hline Leaf $\mathrm{K}$ & 16.224 & 1 & 16.224 & $9.46^{* *}$ & 5.923 \\
\hline Error & 27.434 & 16 & 1.715 & & \\
\hline Total & 172.157 & 3 & 57.386 & $44.93 * * ”$ & \\
\hline Leaf $\mathrm{K}$ & 13.094 & 1 & 13.094 & $10.25^{* *}$ & 4.217 \\
\hline Error & 63.859 & 50 & 1.277 & & \\
\hline \multicolumn{6}{|c|}{ C. 7July-3 Aug. } \\
\hline Leaf $\mathrm{K}$ & 908.161 & 1 & 908.161 & $137.22 * * *$ & 11.216 \\
\hline Error & 105.896 & 16 & 6.618 & & \\
\hline Linear & 44.826 & 1 & 44.826 & $20.95 * * *$ & \\
\hline Leaf $\mathrm{K}$ & 44.730 & 1 & 44.730 & $20.90 * * *$ & -12.416 \\
\hline Error & 34.240 & 16 & 2.140 & & \\
\hline Total & 125.491 & 2 & 62.746 & $28.13 * * *$ & \\
\hline Leaf $\mathrm{K}$ & 28.554 & 1 & 28.554 & $12.80 * *$ & -7.958 \\
\hline Error & 73.600 & 33 & 2.230 & & \\
\hline
\end{tabular}

Table 3. Mean leaf and fruit $\mathrm{K}$ accumulation rates of all study French prune trees for 28 Apr.-28 May, 28 May-7 July, and 7 July-3 Aug.

\begin{tabular}{llr}
\hline \hline & \multicolumn{2}{c}{ Accumulation rates } \\
\cline { 2 - 3 } Interval & $\mathrm{mg} \mathrm{K} /$ fruit per day & \multicolumn{1}{c}{$\mathrm{mg} \mathrm{K} /$ leaf per day } \\
\hline 28 Apr.-28 May & $0.237( \pm 0.048) \mathrm{a}$ & $-0.007( \pm 0.005) \mathrm{a}$ \\
28 May-7 July & $0.140( \pm 0.053) \mathrm{b}$ & $0.005( \pm 0.005) \mathrm{b}$ \\
7 July-3 Aug. & $0.267( \pm 0.110) \mathrm{a}$ & $-0.010( \pm 0.007) \mathrm{a}$ \\
\hline
\end{tabular}

"Mean separation within columns at $P=0.001$.

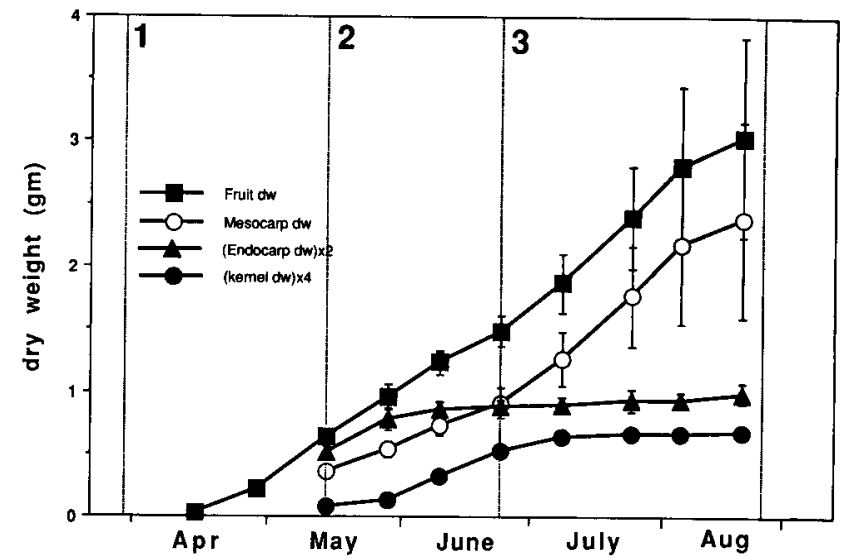

Fig. 6. Whole fruit, mesocarp, (endocarp) $\times 2$, and (kernel) $\times 4$ dry weight (fruit) with time. Fruit growth stages are as in Fig. 1. Bars represent SD. Vertical dotted lines indicate the three stages of prune fruit growth. 
radie, 1981; Greenway and Pitman, 1965; Widders and Lorenz, 1982). Therefore, the June accumulation of fruit and leaf $\mathrm{K}$ in 14 of 18 study trees indicates that, for the majority of the study trees, whole-tree $\mathrm{K}$ demand was satisfied during late stage 2/ early stage 3 of fruit growth. Similar results from peaches and French prune have been reported (Batjer and Westwood, 1958; Hansen et al., 1982).

Reductions in overall tree $\mathrm{K}$ sink strength may have contributed to the June leaf $\mathrm{K}$ increase. By observation, shoot growth ceased by early June. Mean fruit $\mathrm{K}$ accumulation rates were significantly lower in June (O. $140 \mathrm{mg} \mathrm{K}$ per fruit-day) than in May $(0.237 \mathrm{mg} \mathrm{K}$ per fruit-day) and July $(0.267 \mathrm{mg} \mathrm{K}$ per fruitday). The kernel accumulated' dry weight rapidly through June, but little $\mathrm{K}$ (Figs. 2 and 6). The low $\mathrm{K}$ requirement of the kernel (the growth of which dominates fruit growth through June) may explain the low fruit $\mathrm{K}$ accumulation during this period.

The loss of leaf $\mathrm{K}$ with accumulation of fruit $\mathrm{K}$ during July (Figs. 1 and 2) is similar to that in other horticultural crops in which late-season $\mathrm{K}$ efflux from leaves during periods of high fruit $\mathrm{K}$ accumulation/fruit maturation have been reported (Batjer and Westwood, 1958; Smith et al., 1987; Sparks, 1977). The change from positive (June) to negative (July) linear regression coefficient (Table $2 \mathrm{~B}, \mathrm{C}$ ) allows speculation that a reduction of soil $\mathrm{K}$ availability, an increase in fruit $\mathrm{K}$ demand, or a combination of both occurred from June to July-during the first weeks of stage 3 of fruit growth. The largest increase in fruit $\mathrm{K}$ and dry weight accumulation occurred during July (Figs. 2, 5, and 6). Hansen et al. (1982) suggested that late-season Kdeficiency symptoms of French prune are caused by a reduction in root carbohydrate levels and activity due to higher fruit carbon demand and a resulting decrease in soil $\mathrm{K}$ uptake. Mean fruit $\mathrm{K}$ accumulation was higher during July (0.267 mg K per fruit-day) than in June (O. $140 \mathrm{~K}$ per fruit-day). Reduced above-ground (fruit and vegetative tissue) accumulation rates and foliar $\mathrm{K}$ deficiency symptoms have been measured in determinate processing tomatoes (Lycopersicon. esculentum Mill.) (fruit percent $\mathrm{K}=4.00$ by dry weight) during fruit maturation (Widders and Lorenz, 1982). Determination of seasonal changes in carbohydrate and $\mathrm{K}$ levels in roots, leaves, and fruit is required to test the hypothesis of Hansen et al. (1982) and possibly explain the change in leaf $\mathrm{K}$ net flux direction for high- $\mathrm{K}$ trees from stage 2 to midstage 3 of fruit growth.

Since root growth is important to K uptake (Barber, 1985) and fruit growth reduces root growth (Hansen, 1980; Williamson and Coston, 1989), an interaction between fruit growth and leaf $\mathrm{K}$ was expected. However, periods of leaf $\mathrm{K}$ net efflux and fruit growth did not coincide exactly (Fig. 1). As suggested above, seasonal root, leaf, and fruit carbohydrate and $\mathrm{K}$ data are needed before conclusions can be reached regarding fruit development and leaf $\mathrm{K}$ levels.

In comparing leaf and fruit accumulation rates between May and June or July, it must be remembered that crop load and leaf count differed considerably between trees of different $\mathrm{K}$ status in June and particularly July. As fruit percent $\mathrm{K}$ was similar for all trees through stage 3 (Table 1), and fruit $\mathrm{K}$ is correlated with fruit dry matter accumulation (Hansen et al., 1982), an important factor contributing to the differences in leaf and fruit $\mathrm{K}$ accumulation rates in June and July between high and low $\mathrm{K}$ trees may have been carbon availability to the fruit. Such differences were not pronounced in May. Data regarding changes in canopy size, leaf: fruit ratios, with time between May, June, and July, are needed when comparing leaf and fruit $\mathrm{K}$ data in Figs. 3-5.
This study examined the temporal relationship between leaf and fruit $\mathrm{K}$ content in trees of differing $\mathrm{K}$ levels, and investigated the possible influence of fruit growth on this relationship. Positive linear relationships for leaf and fruit $\mathrm{K}$ accumulation rates existed from 28 Apr.-28 May and from 28 May-7 July. A negative linear relationship for leaf and fruit accumulation rates existed from 7 July-3 Aug. Mean fruit K accumulation rates were significantly higher in May and June than in July. The opposite pattern was observed in leaves, with higher mean leaf $\mathrm{K}$ accumulation rates in June than in May and July. Summer efflux of leaf $\mathrm{K}$ did not begin until 2 weeks after initiation of stage 3 . The dry weight and $\mathrm{K}$ accumulation in stage 3 was confined to the mesocarp.

\section{Literature Cited}

Barber, S.A. 1985. Potassium availability at the soil-root interface and factors influencing potassium uptake, p. 277:308. In: R.D. Munson (cd.). Potassium in agriculture. ASA-CSSA-SSSA, Madison, Wis..

Batjer, L.P. and M.N. Westwood. 1958. Seasonal trends of several nutrient elements in leaves and fruits of Elberta peach. Proc. Amer. Soc. Hort. Sci. 65:116-126.

Brown, A. L., J. Quick, and G.J. De Boer. 1973. Diagnosing potassium deficiency by soil analysis. CaIif. Agr. 27:13-14.

Conners, C.H. 1919. Growth of fruits of peach. New Jersey Agr. Expt. Sta. Annu. Rpt. 40:82-88.

Conradie, W.J. 1981. Seasonal uptake of nutrients by Chenin Blanc in sand culture: II. Phosphorous, potassium, calcium, and magnesium. S. Afr. J. Enol. Vitic. 2:7-13.

Dixon, W .J. (cd.). 1985. BMDP statistical software. Univ. of California Press, Berkeley.

Golomb, A. and E.E. Goldschmidt. 1987. Mineral nutrient balance and impairment of the nitrate-reducing system in alternate-bearing 'Wilking' Mandarin trees. J. Amer. Soc. Hort. Sci. 112:397401.

Greenway, H. and M.G. Pitman. 1965. Potassium retranslocation in seedlings of Hordeum vulgare. Austral. J. Biol. Sci. 18:235-247.

Hansen, P. 1980. Crop load and nutrient translocation, p. 201-212. In: D. Atkinson, J.E. Jackson, R.O. Sharples, and W.M. Wailer (eds.). Mineral nutrition of fruit trees. Butterworths, Boston.

Hansen, P., K. Ryugo, D.E. Ramos, and L. Fitch. 1982. Influence of cropping on $\mathrm{Ca}, \mathrm{K}, \mathrm{Mg}$, and carbohydrate status of French prune trees grown on potassium limited soils. J. Amer. Soc. Hort. Sci. 107:511-515.

Head, G.C, 1967. Effects of seasonal changes in shoot growth on the amount of unsuberized root on apple and plum trees. J. Hort. Sci. 42:169-180.

LiIleland, O. 1932. Experiments in $\mathrm{K}$ and $\mathrm{P}$ deficiencies with fruit trees in the field. Proc. Amer. Sot. Hort. Sci. 29:272-276.

Lilleland, O. and J.G. Brown. 1938. The potassium nutrition of fruit trees H. Leaf analysis. Proc. Amer. Soc. Hort. Sci. 36:91-98,

Mengel, K. 1985. Potassium movement within plants and its importance in assimilate transport, p. 397-411. In: R.D. Munson (cd.). Potassium in agriculture. ASA-CSSA-SSSA, Madison, Wis.

Niederholzer, F.J.A. 1990. Seasonal partitioning of dry matter and mineral nutrients in leaves and fruit of french prune (Prunus domestics L. C V. d'Agen) trees of differing potassium status. M.S. Thesis, Univ. of California, Davis.

Olson, W., K. Uriu, R.M. Carlson, W.H. Kreuger, and J. Pearson. 1987. Correcting potassium deficiency in prune trees is profitable. Calif. Agr. 41:20-21.

Rogers, B.L. and L.P. Batjer. 1953. Seasonal trends of several nutrient elements in Delicious apple leaves expressed on a per cent and unit area basis. Proc. Arner, Soc. Hort. Sci. 61:1-5.

Ryugo, K., N. Nii, M. Iwata, and R.M. Carlson. 1977. Effect of fruiting on carbohydrate and mineral composition of stems and leaves of French prune. J. Amer. Soc. Hort. Sci. 102:813-816.

Smith, G. S., C.J. Clark, and H.V. Henderson. 1987. Seasonal accu- 
mulation of mineral nutrients by kiwifruit. I. Leaves. New Phytol. 106:81-100.

Sparks, D.S. 1977. Effects of fruiting on scorch, premature defoliation, and nutrient status of 'Chickasaw' pecan leaves. J. Amer. Sot. Hort. Sci. 102:669-673.

Stassen, P.J. and J.D. Stadler. 1988. Seasonal uptake of phosphorous, potassium, calcium, and magnesium by young peach trees. S. Afr. J. Plant Soil 5: 19-23.

Uriu, K. 1982. Soil and plant analysis and symptomology for diagnosis of mineral deficiencies and toxicities, p. 85-95. In: D. Ramos (cd.). Prune orchard management. Univ. of California Press, Berkeley.
Uriu, K., R.M. Carlson, D.W. Henderson, H. Schulbach, and T.M. Aldrich. 1980. Potassium fertilization of prune trees under drip irrigation. J. Amer. Soc. Hort. Sci. 105:508-510.

Watson, E.B., T.W. Glassey, R.E. Storie, and S.W. Cosby. 1929. Soil survey of Chico area, California. U.S. Publishing Office, Washington, D.C.

Wldders, I.E. and O.A. Lorenz. 1982. Potassium nutrition during tomato plant development. J. Amer. Soc. Hort. Sci. 107:960-964.

Williamson, J.G. and D.C. Coston. 1989. The relationship among root growth, shoot growth, and fruit growth of peach. J. Amer. Sot. Hort. Sci. 114:180-183. 